ВАЛЕРИЈА Б. ЈАНИЋИЈЕВИЋ * МИЛЕНА Б. МИТРОВИЋ Учитељски факултет, Београд
Оригинални научни рад

Примљен: 11. 04. 2019.

Прихваћен: 24. 04. 2019.

\title{
ИЗБОРНИ ТЕКСТОВИ У ЧИТАНКАМА ЗА РАЗРЕДНУ НАСТАВУ КЊИЖЕВНОСТИ
}

\begin{abstract}
Изборни текстови у настави књижевности важни су у истој мери као и они дати програмском лектиром. Њих предлажу аутори читанки (на чији се избор учитељи могу ослонити или не) или их учитељ одабира самостално, на основу својих стручних процена, а водећи рачуна о емоционалном и интелектуалном интересовању ученика. У раду се врши квантитативна и квалитативна анализа изборних текстова у свим одобреним читанкама за школску 2017/18. годину. Будући да нема прецизних обавезујућих упутстава и критеријума за бирање ових текстова, у раду се испитују претпостављени критеријуми и њихово деловање на квалитет наставе књижевности. Ово истраживање може бити од значаја за будуће ауторе читанки, али исто тако и за учитеље, јер се његовим резултатима изоштрава свест о односу прописаних и додатних текстова, о нужној допуни програмске лектире новим делима, као и о пажљивијем одабиру и функцији изборних текстова сходно сензибилитету ученика и наставниковим увидима у најадекватније путеве за стварање младих читалаца.
\end{abstract}

Кључне речи: разредна настава, настава књижевности, наставни план и програм, читанка, лектира, изборни текстови, методичка апаратура.

\section{Увод}

У наставним програмима за предмет Српски језик за млађе разреде основне школе, у делу који се односи на књижевност (конкретно, на лектиру), прописане су, можемо рећи, три врсте текстова: обавезни - разврстани по књижевим родовима и прецизно именовани, усмереноизборни - одређени аутором или жанром, без конкретних наслова (на пример, избор из поезије Душана Радовића или избор из народних лирских песама) ${ }^{1}$ и слободноизборни (изборни/додатни) - без

*valerija.janicijevic@uf.bg.ac.rs

${ }^{1}$ Такође, у свим програмима након књижевних текстова датих у лектири учитељи се усмеравају на научнопопуларне и информативнне текстоаве. У првом и другом разреду назив те целине је „Популарни и информативни текстови”, а у оквиру ње се наводи избор из (илустрованих) енци- 
икаквих прецизнијих упутница које би се односиле на аутора, дело или жанр, осим квантитативног одређења: најмағе два, а највише четири дела (трећи разред), односно најмање три, а највише пет дела (четврти разред). ${ }^{2}$ Док у овом случају наставници и ученици слободно бирају, (мада је та слобода условљена и ограничена на више начина: најпре чињеницом да нема индивидуалног, већ, одељенског избора - избора који важи за све ученике), у случају усмереноизборних и информативних текстова, осим те врсте одређења (која се подразумева) дата су и делом жанровска.

Пре него што могућност једног или другог избора стигне пред наставника и ученика, она је омеђена избором аутора читанке. Можемо рећи да је аутор читанке након састављача програма најслободнији у избору једне и друге врсте текстова (и усмерених изборних и потпуно слободних изборних). Он се може ослањати на искуства претходних аутора читанки, на сопствено искуство и свој књижевни сензибилитет, или процену шта одговара ученицима одређеног узраста, али, у принципу он нема додатних спољних ограничења. Учитељи се даље могу ослонити на избор аутора читанки или текстове одабирати самостално, на основу својих стручних процена, а водећи рачуна о емоционалном и интелектуалном интересовању ученика. У настави књижевности, односно у читању књижевноуметничких текстова врло је важна могућност избора наставника и ученика. Резултати истраживања и ставови бројних истраживача потврђују важност избора у стварању, али и неговању младог читаоца (в. Кларк и Румболд 2006; Гамбрел 1996; Крашен 2004; Санакор 1999). Такође, неоспорна је позитивна веза између избора текста и афективних аспеката читања, као што је мотивација (в. Мосанд и Хендершот 2002; Скрав и др. 1998) или веза између постигнућа и интересантности књижевне грађе (в. Хант 1997). Управо су из ових разлога за учитеље додатни текстови леп изазов, посебно за оне који су у свом раду успели да споје позив и мисију. Учитељи могу изабраним текстовима да допуне или коригују обавезни део програма, да испитују ученички сензибилитет и да, у најсрећнијим тренуцима распоном свог избора покажу како класична и савремена дела једна другима дају нови сјај и додатни смисао. ${ }^{3}$ Улога учитеља при учениковом избору може бити пресудна (Џонс и Ванлеирсбург 1994: 96), а његова могућност да сам бира зависи умногоме од слободе коју пружа програм и од понуђених текстова у читанкама. Упркос свим програмским и уџбеничким ограничењима, обавеза избора додатних текстова добар је подстицај за наставникова и ученичка истраживања и упознавања нових књижевних дела. Лепа је

клопедија и часописа за децу, док је у трећем и четвртом разреду назив „Научнопопуларни и информативни текстови” са упутницом: „Избор из књига, енциклопедија и часописа за децу.” Уз мало додатне упитаности можемо приметити да се ова синтагма за деиу односи само на часописе, или, пак, и на књиге и енциклопедије. То и јесте логично, али није сасвим прецизно наведено.

${ }^{2}$ На ове текстове се упућује у одељку „Допунски избор” (НП 2005: 8; НП 2006: 6).

${ }^{3}$ У правој природи књижевности, односно природи читалачког доживљаја јесте да ученик са истом радошћу прима народне епске песме, на пример, и романе о девојчици Марти Уроша Петровића. 
то прилика за класична дела која су ван програма, као и за савремену, још неканонизовану књижевност, затим за усаглашавање понуђених дела са ученичким сензибилитетом, па и, условно речено, за могућа експериментисања.

Изборни текстови у настави књижевности важни су у истој мери као и они дати програмском лектиром. Овим текстовима ученике треба шире уводити у свет књижевности, а тај свет треба да постане део њиховог искуства. Преко њих се ученици још више упознају са природом саме књижевности. Највише од свега, треба још више да подстакну читање код ученика, снажећи њихову радозналост, као и истраживачки рад у мери у којој је то могуће на овом узрасту. Управо, они могу да прошире поље књижевности и читалачке сензибилности на разноврсне књижевне и некњижевне текстове које ученици нису могли да открију кроз обавезни програм који треба да задовољи друге важне критеријуме, на пример, знања и вредности канонских дела националне и светске књижевности. Додатни избори аутора читанки и учитеља пружају могућност да се у наставу више укључе текстови из савремене литературе, а већ су објављене вануџбеничке хрестоматије подстицајне за учитеље и наставнике (в. Марковић и Митровић 2017). Свакако да изборност текстова у разредној настави књижевности има како ужестручни, тако и шири друштвени значај (в. Јанићијевић и др. 2018a).

Колико је питање изборних текстова у читанкама и настави важно, али и процедурално и методички недовољно прецизирано, показује и број отворених питања која покрећу. Она се тичу саме суштине наставног процеса и обухватају све његове аспекте и све његове учеснике, а допиру и до самих основа наставе књижевности, која, ако је заиста добра (или како то савремена методичка литература воли да назове стваралачка), увек укршта читање као индивидуални чин и заједничку обраду дела на часу. У њој се индивидуално читалачко искуство самерава са искуствима наставника и вршњака. Поменућемо овде само нека од тих питања, а свако од њих може да се грана у више праваца. Прва група питања се односи на знање, спремност и опредељење аутора читанки и учитеља да истражују широко поље књижевности и да бирају одговарајуће текстове. Затим, друго се тиче односа обавезних и изборних текстова. Сада је однос изразито у корист обавезних, али је и отворено питање шта бисмо добили ако би се клатно битно пребацило на страну изборних текстова. За већину учитеља садржај чи-

${ }^{4}$ Изборни текстови посебно су добили на значају након укидања домаће лектире, што је учињено у наставним програмима донетим у пероду од 2004. до 2006. године. За то није постојао ниједан ваљани разлог, поготово не непрецизно позивање на оптерећеност ученика. Постојање домаће лектире омогућава читање дужих дела - романа, као и збирки песама или приповедака, што је неопходно за развијање читалачких склоности, и још више - читалачке страсти. У новим наставним програмима који су усвојени (за први и пети разред основне школе 2017. и за други и шести разред 2018. године) и на којима се ради (за трећи и четврти, односно седми и осми разред) управо се на томе инсистира, јер смо сви у нашем наставничком раду јасно суочени са чињеницом да деца мало читају или, нажалост, нимало. 
танке је истоветан програму, што, макар и мало релативизује однос обавезних и изборних текстова. ${ }^{5}$

У ужем методичком смислу питање изборних текстова се посебно заоштрава када је реч о разредној настави. Учитељ своју креативност мора да усмери на шест или више предметних подручја. Он је у много тежем положају од предметних наставника. Зато му и треба помоћи да би био кретиван. Можда је решење у грађењу програма књижевности са обавезним делима и више група додатних текстова (различитих по жанру, тематици, времену настанка, из српске и светске књижевности...), пропраћених неопходним објашњењима и коментарима, који би омогућавали учитељима да са више поуздања бирају. У свакој од тих група био би знатно већи број предложених текстова, од оног који би учитељ реално могао да бира, следећи потврђене, опште и личне, критеријуме. Тада би и прича о повећању броја изборних текстова имала више смисла и давала више наде за квалитетнијом наставом књижевности у млађим разредима. ${ }^{6}$

Након ових уводних разматрања, која су основа за детаљнија истраживања од значаја за ауторе и програма и читанки, за учитеље, али и за прецизнија одређења у основношколским документима, усмеравамо се на резултате истраживања која се односе на читанке за разредну наставу, тачније на број додатних текстова у уџбеницима, њихову природу и могуће критеријуме одабира.

\section{Методологија истраживања}

Предмет нашег истраживања јесу изборни текстови у читанкама за млађе разреде основне школе. Дескриптивна метода обављена је техником анализе садржаја. Током анализе садржаја свих читанки од првог до четвртог разреда пошло се од поделе књижевних текстова у односу на њихову намену и место у наставном програму: а) обавезни б) усмерени изборни в) слободни изборни (допунски). Извор су представљале читанке за школску 2017/2018. одобрене од стране Министарства просвете. У питању је 34 уџбеника од девет издавача (Завод за уџбенике, Епоха, Eduka, Klett, Креативни центар, Нови Логос, Нова шко-

${ }^{5}$ Снежана Марковић у једном од ретких текстова са сличном тематиком такође увића проблем непостојања свих програмом задатих текстова у читанкама. Она се у свом истраживању бавила читанкама за трећи разред основне школе коришћеним у школској 2007/2008. години.

Читанка би требало да омогући учитељу да у њој нађе све текстове које је у обавези да обради са својим ученицима [...] Чињеница да ни у једној од пет анализираних читанки није заступљен целокупан избор текстова прописаних наставним програмом оставља дилему о ставу који аутори читанке имају према (обавезујућем) наставном програму, али и учитељима који су у обавези да наставни програм реализују у потпуности (Марковић 2008: 62, 65).

${ }^{6}$ Програм Книжевности за деиу и младе, на пример, на Учитељском факултету у Београду пре осам година осавремењен је бројним новим делима домаћих и страних аутора: Драгомир Ђорђевић, Владимир Андрић, Весна Алексић, Корнелија Функе, Јан Мекјуен, Реј Бредбери... Нека од ових дела су, верујемо, и под овим утицајем ушла као обавезна у програме старијих разреда основне школе. Међутим, ово су чинили професори универзитета. Могу ли то тако чинити и учитељи и не постављамо ли пред њих превисоке захтеве? 
ла, БИГЗ и Иновација Јоксимовић). ${ }^{7}$ Наш узорак је потпун јер узима у обзир све одобрене читанке за поменуту школску годину. ${ }^{8}$

Извршена је квантитативна и квалитативна анализа изборних текстова у читанкама. Будући да нема прецизних обавезујућих упутстава и критеријума за бирање додатних текстова у наставним програмима, у раду се испитују претпостављени критеријуми и њихово деловање на квалитет наставе књижевности, полазећи од природе и улоге додатних текстова у разредној настави књижевности.

Да би ово истраживање било ваљано, било је неопходно најпре узети у обзир и број обавезних текстова, тачније однос обавезних и изборних текстова у читанкама. Сходно постављеном циљу формулисани су следећи истраживачки задаци: а) у којој мери садржаји уџбеника српског језика за млађе разреде основне школе поштују принцип обавезности укључивања текстова прописаних програмима; б) у којој мери су у читанкама заступљени слободноизборни текстови у односу на обавезне; в) који је однос усмереноизборних (ограничених најчешће ауторством или жанром) и слободноизборних текстова (без задатог критеријума за њихов одабир); г) каква је природа и који је број слободноизборних текстова по родовима, по ауторству и по односу српске и светске књижевности. На основу тога могло се промишљати о заједничким одликама најзаступљенијих текстова и оних мање заступљених. Такође, настојали смо да испитамо поетичке, тематске, жанровске и смисаоне одлике слободноизборних текстова у односу на одговарајућа својства текстова задатих програмом, и да тако дођемо до могућих критеријума одабира којима су се руководили аутори читанки.

\section{Резултати истраживања и дискусија}

Након анализе свих одобрених читанки за школску 2017/2018. годину дошли смо до изузетно занимљивих података који се тичу структуре читанке у целини, на основу којих се потпуније сагледава централна тема нашег истраживања: број и природа унетих слободноизборних текстова.

\footnotetext{
${ }^{7}$ Потпуни библиографски подаци пописани су у изворима на крају рада.

${ }^{8}$ Истраживање не узима у обзир уџбенике које су одобрени после назначене школске године стога што би узорак био неуједначен с обзиром на чињеницу да би припадао различитим програмским концептима, захтевима и изборима садржаја услед текуће реформе наставе и учења. Ипак, истраживање управо треба да подстакне промишљање на дате теме, скрене пажњу на постојеће проблеме и понуди одређене препоруке за образовне реформе које су у току у области наставе српског језика и књижевности.
} 


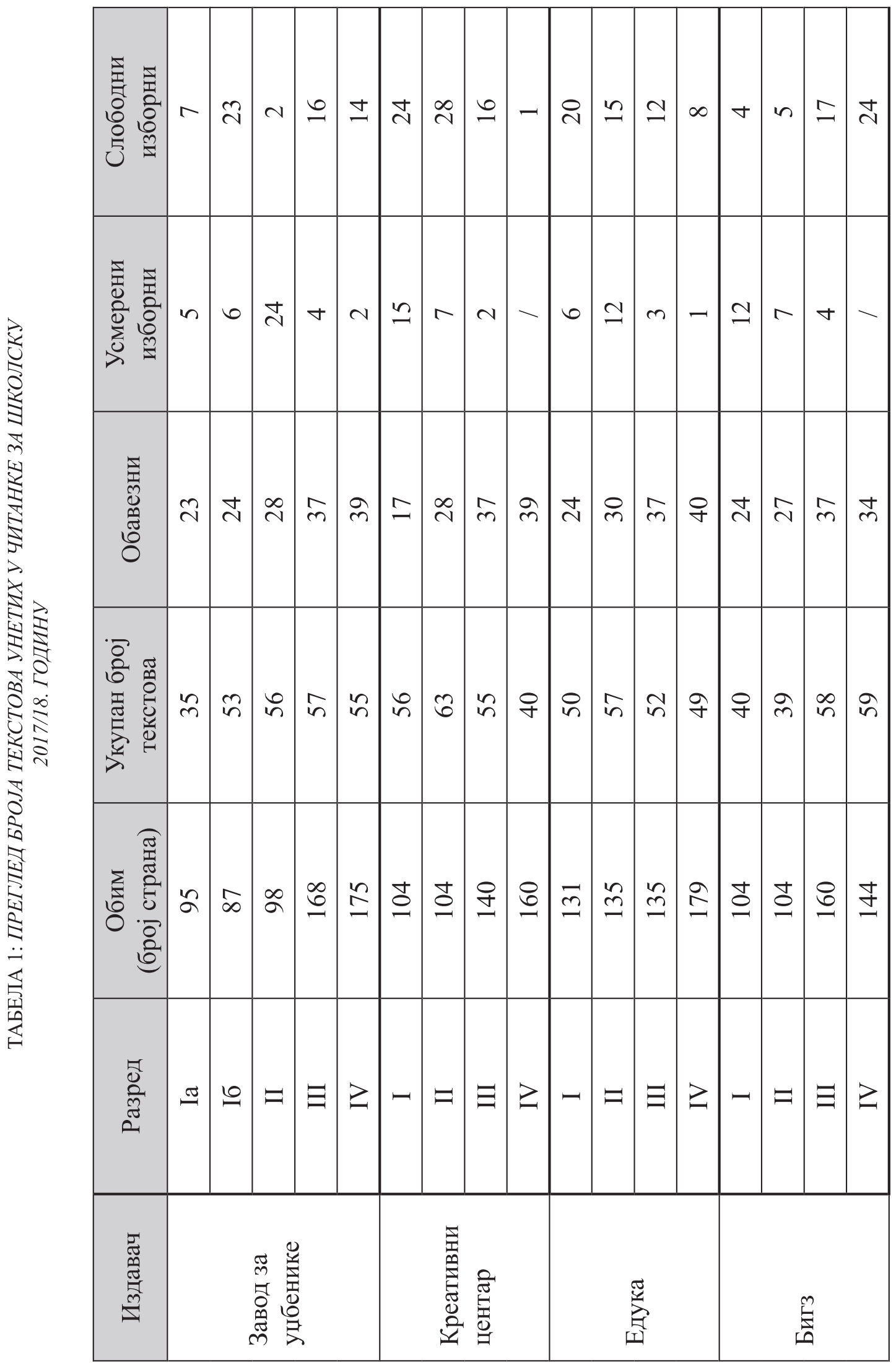




\begin{tabular}{|c|c|c|c|c|c|c|c|c|c|c|c|c|c|c|c|c|c|c|c|}
\hline 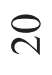 & $\Xi$ & - & $=$ & $\stackrel{\infty}{-}$ & $\gamma$ & $m$ & $r$ & $m$ & $\nabla$ & $=$ & $=$ & $\sim$ & $\gamma$ & - & - & 6 & $\simeq$ & $\grave{\curvearrowright}$ & $\underline{n}$ \\
\hline$\nabla$ & $\infty$ & $\infty$ & - & $r$ & - & $N$ & $\gamma$ & $\widehat{\sim}$ & $\underset{\sim}{\sim}$ & $a$ & $m$ & $\underline{2}$ & $\simeq$ & - & - & 아 & $\stackrel{\sim}{n}$ & 6 & $m$ \\
\hline$\stackrel{\searrow}{\sim}$ & ㅇ & $\hat{n}$ & 우 & $\stackrel{\Xi}{\sim}$ & - & $\hat{n}$ & $\hat{n}$ & $\underset{\sim}{\searrow}$ & 요 & $\hat{n}$ & 아 & $\underset{\sim}{\searrow}$ & 요 & - & - & 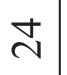 & 요 & $\hat{n}$ & $\stackrel{ }{+}$ \\
\hline$\stackrel{\infty}{+}$ & $\widetilde{\sigma}$ & o & $\tilde{n}$ & gे & - & N & $\underset{\forall}{\forall}$ & $\dot{n}$ & $\ddot{n}$ & $i n$ & in & $\stackrel{\infty}{m}$ & $\underset{广}{\mathcal{Y}}$ & - & - & 웅 & $\underset{\nabla}{*}$ & $\mathbb{N}$ & in \\
\hline$\stackrel{b}{n}$ & $\infty$ & $\stackrel{8}{\circ}$ & $\stackrel{ }{\ddagger}$ & $\triangleright$ & - & $\stackrel{\sim}{\sim}$ & $\stackrel{\sim}{n}$ & $\stackrel{ }{\Xi}$ & $\stackrel{\sim}{\sim}$ & $\stackrel{\infty}{\infty}$ & $\stackrel{\infty}{\sim}$ & $\stackrel{\infty}{\infty}$ & $\stackrel{⿱}{N}$ & - & $\gamma$ & $\cong$ & 운 & ऽ & $\begin{array}{l}\infty \\
\infty\end{array}$ \\
\hline • & $\exists$ & $\Xi$ & $\geq$ & 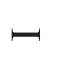 & 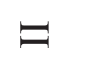 & $\Xi$ & $\geq$ & $\neg$ & $=$ & $\Xi$ & $\geq$ & 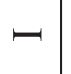 & 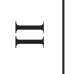 & $\Xi$ & $\geq$ & - & 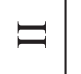 & $\Xi$ & $z$ \\
\hline & 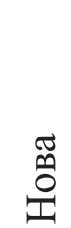 & $\begin{array}{l}\text { 营 } \\
\text { 当 } \\
\text { 甚 }\end{array}$ & & & 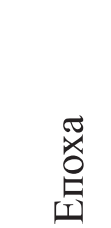 & & & & 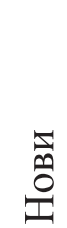 & $\begin{array}{l}0 \\
0 \\
0\end{array}$ & & & 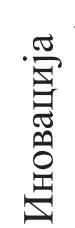 & 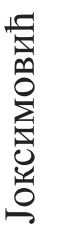 & & & $\frac{E}{\Delta}$ & & \\
\hline
\end{tabular}


Из табеларног прегледа види се број страница читанки, укупан број текстова у њима, број обавезних и изборних текстова. Подаци које смо добили нуде могућност за више аналитичких смерова, од којих неки могу бити само наговештени.

Први податак у табели односи се на број страница одобрених читанки. Из наведених података се види да не постоје упутства, бар не прецизна о обиму читанки по разредима. У првом разреду распон између обимом најмање и највеће читанке је више него двострук 56 страна наспрам 131 стране, у другом је тај однос 87:140, трећем 132:192 и у четвртом 140:228. Из наведеног се види да је највећи распон у првом разреду (па потом у четвртом), за шта нема методичког оправдања. С друге стране, укупан број текстова мање варира у односу на број страница. Опет је највећи распон у првом разреду 35:70 (Завод за уџбенике и Klett), а занимљиво је и да је велики распон у једном разреду код истог издавача (читанке за први разред Завода за уџбенике 35:53). То значи да је последња реч о броју унетих текстова и обиму читанки препуштена самим њиховим ауторима. Податак о броју страница једне читанке сам по себи је вредносно неутралан. Препорука поводом обима читанке може се остварити на два начина: а) да је неопходно дати прецизнија упутства за израду читанки или б) да број страна читанке остане израз воље аутора. ${ }^{9}$

Констатовали смо да има читанки које не садрже све програмом прописане текстове. Наставни програм за млађешколски узраст донет између 2004. и 2006. године прописује следећи број обавезних текстова: за први разред 24 текста, за други разред 30, за трећи 37 и за четврти 39. Од укупног броја анализованих читанки у седам нису унети сви програмом задати текстови. Највећи распон је опет у читанкама за први разред: 17 унетих (Креативни центар) од обавезна 24, али није занемарљив ни у осталим разредима у којима се јавља, посебно у једној читанци за четврти разред (БИГЗ) у којој је 34 текста од 39 обавезних. Ако знамо да Правилник (ПСУК 2016) одређује да одобрене читанке треба да имају све програмом задате текстове, онда је зачуђујуће како су одобрене без њих. Под претпоставком да учитељи у већој мери консултују читанку него програм, можемо поставити логично питање да ли учитељи обрађују неунете обавезне текстове и да ли уопште знају за њих. С друге стране, учитељи без консултовања и упоређивања програма и одабране читанке не могу бити сигурни да ли се у њој налазе сви текстови које обавезно треба да обраде са ученицима (Мркаљ и Плут 2007). Истина је и да у данашње време, због честог ослањања на планове и приручнике издавача, намењене олакшавању наставе, учитељи не освешћују довољно разлику о двема врстама текстова. Уз све то, ни у програму ни у правилницима не постоје упутства ауторима читанки нити учитељима о критеријумима одабира допунских текстова. ${ }^{10}$

\footnotetext{
${ }^{9}$ Детаљнија анализа односа броја унетих текстова и броја страна би могла да укаже на број и обим унетих изборних текстова, као и богатства и разноврсности методичке апаратуре.

${ }^{10}$ Којим се критеријумима воде учитељи при одабиру додатних текстова за читање и обраду у настави, и да ли се и колико ослањају на већ понуђене изборе у читанама, јасно се види на истра-
} 
Што се усмереноизборних текстова тиче, као и у претходном случају, будући да нема прецизнијих упутстава, аутори су се ослонили на своје критеријуме и свој књижевни осећај. У првом разреду у читанкама се број ових текстова креће од 4 (Нова школа) до 40 (Klett). У другом од 6 до 32. У трећем од 2 до 9 и у четвртом од једног до 3. Ови подаци могу праву вредност добити тек када се укрсте са програмским налозима о жанру и аутору.

Слични су подаци и о слободноизборним текстовима. И код њих је велика диспропорција: од 2 до 24 у првом разреду. Од 4 до 28 у другом, од једног до 29 у трећем и у четвртом од једног до 24 . Непостојање планског и јасног односа према заступљености изборних текстова најбоље се види ако сагледамо издаваштво по разредима једне издавачке куће. Тако примећујемо низ занимљивих података. Завод за уџбенике и наставна средства има две одобрене читанке за први разред: у једној постоји 7 текстова по слобном избору аутора, а у другој чак 23. Ако погледамо читанке једног издавача од првог до четвртог разреда, тешко да можемо да уочимо било какву логику у броју изборних текстова. Код једних је највише изборних текстова у првом разреду, код других у другом, код трећих у трећем. Само у једном случају (БИГЗ) примећујемо растући број изборних текстова из разреда у разред ( $\rightarrow 5 \rightarrow 17 \rightarrow 24)$. Са друге стране, у једном случају - сасвим је супротна ситуација (Eduka $20 \rightarrow 14 \rightarrow 9 \rightarrow 8$ ). Код једног броја издавача имамо одсуство било каквог јасног система када је у питању однос броја додатних текстова и узраста ученика. Тако је у читанкама Нове школе: $20 \rightarrow 14$ $\rightarrow 1 \rightarrow 11$, или издавачке куће Klett: $6 \rightarrow 12 \rightarrow 29 \rightarrow 13$. Можда овакав поглед аутора најизразитије долази до изражаја у читанкама Креативног центра: $24 \rightarrow$ $28 \rightarrow 16 \rightarrow 1$. Очигледно је да узраст ученика не представља један од битних критеријума приликом одлучивања самих аутора о броју текстова, а то би, сматрамо, свакако требало да буде први критеријум, јер се читалачке способности ученика повећавају са сваком новом школском годином. С друге стране, није неважно о колико сложеним и захтевним изборним текстовима се ради, те тако је могуће претпоставити концепт читанке у којој се текстови из разреда у разред усложњавају, а број текстова због тога опада. Овакав концепт нисмо уочили у анализираним уџбеницима.

Детаљнија анализа слободноизборних текстова дата је у другој табели. На неки начин њима је овде делом приступљено иманентно методички, водећи рачуна о њиховим општијим књижевним својствима. У приказаној табели дела унета у читанке разврстана су: а) по жанровима и врстама, б) по пореклу (народна и ауторска) и в) према припадности аутора домаћој или светској књижевности.

живању које је обухватило 255 учитеља из 28 основних школа широм Србије (в. Јанићијевић и др. 2018a). 


\begin{tabular}{|c|c|c|c|c|c|c|c|c|c|c|c|c|c|c|c|c|c|}
\hline 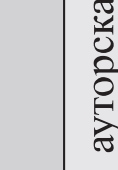 & $r$ & $\approx$ & $N$ & $\simeq$ & 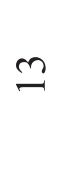 & $\vec{\sim}$ & $\stackrel{\sim}{\sim}$ & & - & 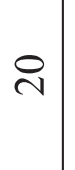 & $\Xi$ & $a$ & $\infty$ & $m$ & $\nabla$ & 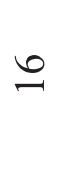 & $\stackrel{\curvearrowright}{\sim}$ \\
\hline 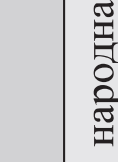 & - & - & - & $n$ & - & $N$ & 6 & - & - & - & $\neg$ & $m$ & - & - & - & $\gamma$ & $m$ \\
\hline 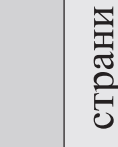 & $\sim$ & $\sim$ & - & - & $\sim$ & $n$ & $\infty$ & $\nabla$ & - & $m$ & 6 & $\sim$ & - & - & - & $m$ & $\infty$ \\
\hline 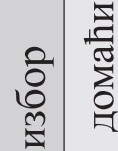 & $n$ & 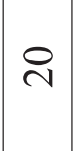 & $\sim$ & $\simeq$ & $=$ & $\stackrel{\ddots}{-}$ & $\simeq$ & 6 & - & I & $\infty$ & $r$ & - & $N$ & $m$ & $\stackrel{m}{n}$ & $\simeq$ \\
\hline 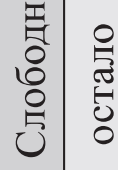 & - & - & - & - & - & - & $N$ & $n$ & - & $\gamma$ & - & - & - & $\gamma$ & - & - & - \\
\hline 豆 & - & - & - & - & $N$ & - & - & - & - & - & $\gamma$ & $\gamma$ & - & - & $\gamma$ & $\gamma$ & - \\
\hline $\begin{array}{l}\sum_{\mathbb{J}}^{\pi} \\
\stackrel{\tilde{D}}{E}\end{array}$ & - & - & - & - & - & - & - & - & -1 & $\gamma$ & - & - & - & - & - & - & N \\
\hline 荧 & - & $\infty$ & $N$ & $r$ & $\nabla$ & $r$ & \pm & 6 & -1 & 6 & $=$ & 6 & $\sim$ & $N$ & $\nabla$ & $\infty$ & $m$ \\
\hline $\begin{array}{l}\tilde{3} \\
\text { : }\end{array}$ & $r$ & \pm & - & $\infty$ & $\infty$ & $\stackrel{0}{0}$ & $\simeq$ & $\nabla$ & -1 & $\Xi$ & $\nabla$ & 0 & 6 & - & $\gamma$ & $\infty$ & $\infty$ \\
\hline 号 를 & $\widetilde{\Xi}$ & 10 & $=$ & $\Xi$ & $\geq$ & 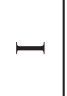 & $=$ & $\Xi$ & $\geq$ & $\neg$ & $\Xi$ & $\Xi$ & $\geq$ & $\neg$ & $\exists$ & $\Xi$ & $\geq$ \\
\hline 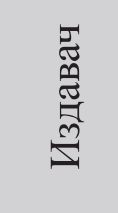 & & & 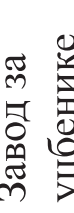 & & & & 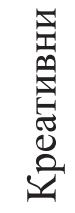 & 范 & & & 齐 & & & & 约 & & \\
\hline
\end{tabular}




\begin{tabular}{|c|c|c|c|c|c|c|c|c|c|c|c|c|c|c|c|c|c|c|c|}
\hline$\underline{-}$ & $n$ & - & $\stackrel{ }{\circ}$ & 工 & $\gamma$ & 6 & $m$ & 一 & $\sim$ & 6 & $m$ & $\gamma$ & $\gamma$ & - & $\gamma$ & $\nabla$ & 二 & $\bar{N}$ & $\mathcal{\sim}$ \\
\hline - & - & - & - & - & - & $\sim$ & $N$ & - & - & - & - & - & - & - & $\gamma$ & - & - & $m$ & - \\
\hline 6 & $m$ & $\gamma$ & $m$ & $n$ & - & - & 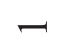 & - & $\gamma$ & $N$ & $\nabla$ & $\gamma$ & - & - & $\gamma$ & - & - & $m$ & $\mathrm{~N}$ \\
\hline 으 & $\stackrel{0}{\circ}$ & - & $N$ & $=$ & $\gamma$ & $n$ & $N$ & 一 & $\sim$ & $\nabla$ & $m$ & $\gamma$ & - & - & $\gamma$ & $m$ & 으 & $\infty$ & 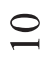 \\
\hline$\neg$ & - & - & $N$ & $\gamma$ & $\gamma$ & $n$ & $N$ & $N$ & - & $\nabla$ & $\nabla$ & - & - & - & $\gamma$ & $\sim$ & $\gamma$ & $n$ & $\gamma$ \\
\hline$\gamma$ & $\gamma$ & $\gamma$ & $\sim$ & $\gamma$ & $\gamma$ & $\gamma$ & $N$ & - & $\gamma$ & - & - & $\gamma$ & $\gamma$ & $\gamma$ & $\gamma$ & $\gamma$ & $\gamma$ & $\gamma$ & $\sim$ \\
\hline N & $N$ & $\gamma$ & - & - & - & - & - & - & $\gamma$ & $\gamma$ & $\gamma$ & $\gamma$ & - & $\gamma$ & $\gamma$ & - & $\gamma$ & - & $\gamma$ \\
\hline$a$ & $\simeq$ & 一 & $n$ & 으 & $\gamma$ & $m$ & $m$ & $\gamma$ & $\sim$ & $\nabla$ & $\nabla$ & - & $\gamma$ & $\gamma$ & $>$ & $m$ & $\nabla$ & $\simeq$ & $\nabla$ \\
\hline$\infty$ & - & $\gamma$ & $m$ & $\infty$ & - & $n$ & - & - & - & $m$ & $N$ & - & $\gamma$ & $\gamma$ & $\gamma$ & $\gamma$ & $\infty$ & $\simeq$ & $N$ \\
\hline • & $\sqsupseteq$ & $\Xi$ & $\geq$ & • & ヨ & $\Xi$ & $\gtrsim$ & • & $\Xi$ & $\Xi$ & $\geq$ & • & $\Xi$ & $\sqsupseteq$ & $\geq$ & 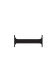 & $\sqsupseteq$ & $\Xi$ & $\geq$ \\
\hline & 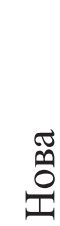 & $\begin{array}{l}\text { 菅 } \\
0 \\
\text { 当 }\end{array}$ & & & & & & & 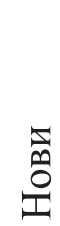 & $\begin{array}{l}0 \\
0 \\
0 \\
0\end{array}$ & & & 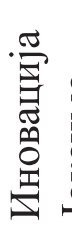 & 党 & & & & & \\
\hline
\end{tabular}


Жанровска разврставања показују очигледну надмоћ лирских и епских дела, и у тој сразмери да су ова два жанра заступљена са три четвртине, па и више унетих текстова у читанкама по слободном избору аутора. Међутим, однос међу њима се мења зависно од издавача и зависно од разреда. У прва два разреда очекивала би се превласт краћих књижевних текстова, најпре лирских над епским, али табела показује њихову уједначеност, осим у граничним случајевима (Завод за уџбенике, први разред - 1a: 7 лирских и ниједно епско, док обрнути случај нуди БИГЗ у другом разреду: ниједно лирско и четири епска, и посебно Нова школа у трећем разреду: једно лирско и 12 епских).

Карактеристично је да су драмска дела мало заступљена у слободним изборима, док их пет издавача уопште не уноси ни у једном разреду. Два издавача доносе само по један драмски текст и то у првом разреду. Од два преостала издавача један доноси 5, а други 3 текста у читанкама за све разреде. Готово иста ситуација је и са делима научнопопуларне књижевности: девет издавача у свим читанкама за млађи узраст доносе укупно 10 ових текстова. Нешто већих број је информативних текстова, дечјих радова и слично (у табели под остало), што је последица програмских захтева, али и њих би морало бити неупоредиво више.

Друге две класификације дају очекиване резултате. Дела српских аутора су вишеструко заступљенија у односу на дела светских. Укупно је 252 текстова српских писаца и 81 текст светских, а то је 76\% према 24\%. Нема већих одступања од ове опште тенденције ни код појединачних издавача. Иако је реч о избору у којем су аутори могли слободније да се односе према разним ограничењима, они су сматрали да ученицима треба понудити углавном дела написана на матерњем језику, а не преведена. Сличан је однос и између дела народне и ауторске књижевности (38: 3, то је 90\% према 10\%). За разлику од претходног случаја однос ауторске и народне књижевности би могао да се тумачи на више начина. Са једне стране, аутори су предност дали ономе што је ближе дечјем сензибилитету, што је сасвим корисно за њихово увођење у читање. С друге стране, највреднија дела народне књижевности имају вишеструки уметнички и мисаоно-логички значај на овом узрасту, служе развијању емпатије и уопште етичком одношењу читалаца према проблемским животним ситуацијама и моралним идеалима, а веома су погодна и за развијање језичких способности. С обзиром на функцију коју имају, њихов број је могао да буде и већи. Остаје питање да ли је, с обзиром на улогу коју могу да имају, њихов број могао да буде већи.

На основу прегледа датог у другој табели можемо закључити да драмски текстови, научнопопуларна дела, као и текстови народне књижевности ретко представљају избор аутора читанки. Они се у највећем одлучују за ауторске лирске или епске текстове. Најпрецизније, у питању су песме и краће приче. Уз то, много више су заступљена дела домаћих стваралаца. Однос између националне и стране књижевности је чак вишеструко већи у корист националне. Најизразитије то видимо код следећих примера: у читанкама издавачке куће Klett имамо 10 текстова домаћих аутора и један страни у другом разреду. Тај однос је 18:3 у трећем и 10:2 у четвртом разреду. Слично је и са читанкама за први разред Креа- 
тивног центара, Епохе и Eduke: 16:5, 11:5 и 17:3. Ако пођемо од претпоставке да су се аутори читанки водили ставом да ученицима најмлађег школског узраста најпре треба понудити што више дела домаћих аутора, а да се, што су старији тај однос домаћи-страни и више мења, односно разлика међу њима се смањује, видећемо да ипак ни ово није концепт актуелних издавача. Тако, на пример, код Eduke у остала три разреда имамо однос: 8:6, 7:2 и 7:1. Разлика је најмања у другом разреду, а касније се опет повећава.

\section{Критеријуми одабира изборних текстова}

Изборни текстови, као и програмом задати, у првом разреду најпре су у функцији стицања и увежбавања вештине почетног читања и писања. Уметничка вредност текстова и усвајање одређених књижевних знања су следећи наставни циљ у првом разреду. Наше промишљање о претпостављеним критеријумима одабира разноврсних додатних текстова у читанкама усмерили смо на други, трећи и четврти разред, узевши у обзир чињеницу да је у првом разреду превасходни захтев за описмењавањем ученика. ${ }^{11}$

Наставом књижевности у другом разреду ученик стиче конкретна знања о књижевном тексту: препознаје различите књижевне врсте, усваја и именује доминанте вредности уметничког текста и друго. Изборни текстови, с тога, имају важну улогу у формирању трајних читалачких навика и афирмативног става према књижевности и тумачењу књижевног текста. У читанци за други разред издавача Нове школе изборне текстове чине песме, приче, басне и драмски текст: заступљеност различитих књижевних врста свакако је био један од критеријума за одабир текстова. Ови текстови разноврсне структуре могу бити одговарајућа допуна обавезним програмским текстовима јер ће ученици другачијим начинима обликовања текста бити мотивисани за читање и разговор о њима. Сасвим другачији приступ је примењен у читанци издавачке куће Eduka (Манојловић и Бабуновић 2016). На почетку уџбеника су песме које су тематски везане за лето и јесен („На крају лета” Гордане Илић и „Октобар” Божидара Тимотијевића), док је на крају уџбеника песма о пролећу („Пролећни распоред часова" Љиљане Крстић). Тематске целине условно прате годишњи календарски циклус. Осим Бранка Ћопића са текстом „Изокренута прича”, у слободном избору преовлађују аутори који нису заступљени у обавезној лектири за други разред и који нису „типични” школски писци: Божидар Тимотијевић, Драган Лакићевић и Игор Коларов. Поред домаћих писаца, аутори уџбеника су се определили за текстове (најчешће приче) страних писаца: Астрид Линдгрен, Луција Тумијати, Артур Шопенхауер и Халфдан Расмусен. Иако је избор страних писаца можда и неочекиван, теме о којима пишу у изабраним текстовима су сагласне

\footnotetext{
${ }^{11}$ Осим тога, на тржишту и у настави првог разреда су нове читанке углавном истих издавачких кућа прилагођене реформисаним програмима наставе и учења, те из тог разлога изборни текстови у њима нису били предмет детаљније анализе.
} 
узрасту и подстицајне за тумачење - прича о лепом понашању где ликови животиња преносе јасну моралну поруку („Бодљикава прасад” Артур Шопенхауер), нетипично компонована песма која читаоцима у хиперболизованом и духовитом облику представља библијску личност Голијата („Шта Голијат може” Халфдан Расмусен) итд.

У три читанке за други разред издавача БИГЗ, Нови Логос и Завод за уџбенике (Јузбашић и Тркуља 2008; Станковић-Шошо 2015; Јовановић 2015) примећује се благ утицај обавезних текстова из програма на избор додатних. Илустративни пример је прича Симеона Маринковића „Свети Сава и млад човек” у читанци издавачке куће БИГЗ и која је, делом, одабрана под утицајем обавезног текста из лектире „Свети Сава, отац и син”. Вероватно је и да су аутори желели да ученици увиде везу народне и ауторске књижевности. Ово је тек један од бројних примера у којима ученици сагледавају како се теме, мотиви, књижевни облици или приповедни поступци из народне књижевности преузимају и обликују у текстове ауторске књижевности. Као изборни текст у читанци истог издавача доноси се басна „Коњ и магаре” Доситеја Обрадовића, уместо програмом задате народне басне „Коњ и магарац”. У овом примеру можда је реч о превиду аутора јер програмом задатог текста народне басне, која је садржински другачија од Доситејеве верзије, нема. Сличан пример је и са изборним текстом „Мачак отишао у хајдуке” Бранка Ћопића који је заменио по програму обавезни „Доживљаји мачка Тоше” истог аутора.

Међу изборним текстовима у читанкама издавачких кућа Нова школа (Ћук и Петровић-Периц 2009), Eduka и БИГЗ преовлађује прича, док се у читанци Креативног центра уочава равномерност поезије и прозе. Поред овог, донекле равномерног, смењивања песама и прича (у поменутој читанци), уочава се да је циљ изборних текстова био усвајање, обнављање или проширивање знања о програмом прописаним књижевнотеоријским појмовима. Тако се уз текст „Забринути родитељи" Андре Франчевић покреће знање о особинама лика и причи, уз руску народну басну „Лија и ждрал” обнавља се појам басне, уз Змајеву песму „Добри пријатељи” утврђује се препознавање појмова стих, строфа и рима, док се уз народну причу „Лакоми мечићи” ближе одређује појам место радње у књижевном тексту.

У уџбенику издавачке куће Klett (Жежељ Ралић 2016a) постоји мањи број изборних текстова, што је урађено с разлогом јер се доноси велики број песама аутора који су део обавезног програма (8 песама Љубивоја Ршумовић и 10 песама Добрице Ерића). Занимљиво је да „Избор из Антологије савремених српских песама" обухвата 11 песама од којих су 3 из Радовићеве Антологије српске поезије за децу, што и јесте програмско усмерење, док 8 песама савремених српских песника припадају изборном делу. Реч је о веома добром поступку, јер је ауторка испоштовала програмски захтев са три песме, али је донела и свој избор песама.

Ако би требало теме и мотиве свих изборних текстова из читанки за други разред систематизовати, онда се лако уочава да доминирају мотиви природе, де- 
чије игре, пустоловине и несташлуци, фантастични догађаји, текстови који носе јасну моралну поруку или који су шаљивог тона, односно све што је у сагласју са претпостављеним сензибилитетом ученика другог разреда. Аутори уџбеника одабиром изборних текстова настоје да учине важан корак ка настави књижевности у трећем разреду где се очекује усложњавање тема, мотива и структуре и обавезних и изборних књижевних текстова.

У читанци за трећи разред издавача Нови Логос (Станковић-Шошо и Костић 2016б) врло је скроман број изборних текстова. Ученицима ван програмских текстова понуђене су 3 лирске песме домаћих аутора: Милана Ракића, Драгана Лукића и Десанке Максимовић. Важно је напоменути да стваралаштво Милана Ракића није програмом прописано у млађим разредима основне школе, па је утолико избор ове песме драгоцен као упознавање са песником којег ће читати у старијим разредима. У читанци су и 3 прозна текста, бирана са јасном функцијом. Први текст, басна „Цврчак и мрав”, утврђује ученичка знања о овој књижевној врсти и кореспондира са програмском Езоповом басном „Корњача и зец”, народном басном „Вук и јагње”, арапском народном причом „Лав и човек”, али и са причама „Свитац тражи пријатеља” Сун Ју Ђина и „Причом о доброј роди” Стојанке Грозданов Давидовић. Други текст је шаљива народна прича „Јао, жено, изједе ме вук” која је у вези са народним приповеткама из обавезног програма и употпуњује знање ученика о народној књижевности. Трећи текст јесте одабрани одломак из романа Пипи Дуга Чарапа Астрид Линдгрен, што надокнађује програмско одсуство ове књижевне врсте. Претпостављамо да је избором одломка у којем јунакиња девојчица Пипи приређује читаоцима различите неочекиване авантуре, аутор уџбеника желео да мотивише ученике за читање целовитог и, у односу на обавезне програмске текстове, обимнијег књижевног дела. Избор је употпуњен афоризмима Александра Чотрића, вероватно с циљем да се ученицима на духовит начин - приближи још једна књижевна врста.

Читанка издавачке куће Klett (Жежељ Ралић 2016б) садржи највећи број додатних текстова, најразноврснији су и на различите начине употпуњују програмске обавезне текстове. Најпре су ту уводне песаме („Кад на свет дођеш бели” Драгомир Брајковић, „Моја улица” Милосава Мијовић) које служе више као позив за игру и увођење у дечије теме. Ауторска песма „Успаванка” Милосаве Мијовић, настала по народном обрасцу, на својеврстан начин допуњује програмом задат садржај - обичајне народне лирске песме и ученицима пружа увид у непрекидну везу савремене и традиционалне књижевности. У једном броју песама истичу се вредности српске културе („Вуков завет” Драгутин Огњановић и „Христов сан” Крстивоје Илић), што је битан програмски задатак наставе Српског језика уопште. О промишљању књижевног (песничког) језика и његовим могућностима ученици читају у изборним песмама „Река речи” Милосаве Мијовић и „Како се пишу песме” Владе Стојиљковића. Песме су значајне јер на леп и ученицима прихватљив начин покрећу теме о којима се не говори довољно у млађим разредима основне школе, а то су настајање једне уметничке творевине и језик у књижевноуметничком тексту. 
Изборне прозне текстове у овој читанци чине прича „Сиви” Светлане Велмар Јанковић и „Сребрни кључ и шарени хлеб” Милорада Павића. Први текст је одломак из приче „Златно јагње” која је део веће целине, тј. Къиге за Марка. Није јасан критеријум одабира одломка приче из два разлога: прво, смисао целовите приче губи се читањем једног њеног дела, друго, причу „Златно јагње” ће ученици вероватно имати прилику да читају као део обавезне лектире у четвртом разреду. ${ }^{12}$ Овде је врло важно истаћи да аутори уџбеника, али и учитељи који бирају уџбенике треба да имају на уму шта је све ученик могао да чита или читао у претходном разреду, али и шта ће читати у наредном, и у погледу обавезних и изборних текстова. „Сребрни кључ и шарени хлеб” Милорада Павића јесте прича о верности и поштењу, али је далеко занимљивија необична структура романа из којег је узет одломак. Реч је, сасвим у Павићевом духу, о двосмерној књизи Невидливо огледало - прича за девојчице чита се са једне стране књиге, а Шарени хлеб - прича за дечаке са њене друге стране. Може се рећи да постоје два улаза у роман, што није уобичајно за школска дела; вероватно је аутор очекивао да их таква нетипична организација текста додатно мотивише. Иако у читанци нису дате сугестије, важно би било да учитељ кроз локализацију одломка приволи ученике да прочитају овај необичан роман. За одломке из романа Збирка марака Карела Чапека и Аги и Ема Игора Коларова претпостављамо да су ауторске исправке обавезног програма у којем уопште нема романа у трећем разреду основне школе. ${ }^{13}$ У читанци су и народна поучна прича „Охолица” и духовита „Кад сам био стар човек” које допуњују обавезне народне приче. Доноси се и басна „Лав и бик” по Доситеју. Није уочљив конкретан разлог за њен избор, осим да се допуни и утврди знање о овој књижевној врсти. Слично је и са краћим, лирски обојеним текстом „Срећа” Пол Фора (нетипичне и дужине и форме за овај узраст), за који можемо рећи да је само додатни украс у овој читанци, без јасне намере аутора уџбеника.

У читанци Креативног центра (Маринковић и Марковић 2016) народна басна као књижевна врста допуњена је следећим текстовима: Лафонтеновим баснама „Градски и пољски миш” и „Цврчак и мрав”, односно, „Камен” Сергеја Михалкова. Ауторски текст Симеона Маринковић „Свети Сава помаже човеку да се снађе” допуњује народну приповетку „Свети Сава и сељак без среће”. „Клин-чорба” допуњује шири избор народних приповедака из програма. Ова читанка има више текстова који нису књижевни, а припадају информативним и научнопопуларним текстовима („Умемо ли да слушамо саговорника”, „Добар друг”, „Нови фризерски салон”). Уочљиво је да су обавезни програмски садржаји били критеријуми, или некаква усмерења, за избор додатних текстова у

${ }^{12}$ Наставним програмом за четврти разред (НП 2006) прописано је да се обавезно чита прича „Златно јагње” и/или (у зависности од тумачења програма) „Стефаново дрво” Светлане Велмар Јанковић.

${ }^{13}$ Како се статус овог књижевног жанра мењао у програмима за разредну наставу књижевности од Другог светског рата до данашњих дана, као и о броју, обиму и тематици романа који су се читали на овом узрасту, видети у: Јанићијевић и др. 2018б: 314-331. 
овој читанци. Из Линдгрениног романа одабран је одломак „Пипи забавља тетка Лауру" што, као и у претходним случајевима, можемо оправдати одсуством ове књижевне врсте из програма (да у овој прилици занемаримо једну од одлика избора додатних текстова, а то је битно међусобно угледање аутора читанки различитих издавача).

Читанка Завода за уџбенике (Милатовић 2015) садржи песме канонских српских стваралаца: Бранислава Петровића („Балада о дечаку који се претворио у лава”), Добрице Ерића („Моје село”) и Десанке Максимовић („Ближи се, ближи лето") као изборне. Прва од њих у самом наслову носи књижевну врсту коју ученици по наставном програму не усвајају као књижевнотеоријски појам. Међутим, у њој је лако уочити и лирске и епске моменте, који су прожети шаљивим тоном и сањарењем једног дечака, те је песма погодна да се ученици упознају бар са природом баладе као жанра. Овим се чини један искорак ван програма који није нефункционалан, већ напротив, подстицајан за ученике и представља увертиру у надоградњу знања у старијим разредима. Друге две песме су тематски интересантне ученицима јер славе природу и певају о доласку лета. Посебно песму Добрице Ерића читљивом чини равномерно смењивање наглашених и ненаглашени слогова што је аутор уџбеника искористио за ширење знања о ритму и ритмичности лирске поезије.

Што се епике тиче, заступљене су приче разноврсног ауторства и порекла: „Бели коњ” америчка народна прича, „Звезде” енглеска народна бајка, Доситејева басна „Магарац у лављој кожи”, „Деца у дворишту” Иве Андрића, „Мачак” Николе Тесле и „Невидљиво огледало” Милорада Павића. Од поменутих примера издвојићемо два. Први, америчку народну причу „Бели коњ”, која кроз дескриптивни израз дочарава лепоту, посебност и неукротивост белог коња. Текст сличног наслова „Бајка о белом коњу” Стевана Раичковића чита се у истом разреду као обавезни програмски. Ове две приче, жанровски и стилски различите, треба да покажу ученицима да исте теме и мотиви функционишу у књижевним делима која припадају различитим временима/епохама. И други пример, изборни текст у читанци Завода за уџбенике јесте одломак из романа за децу Милорада Павића Невидљиво огледало. Текст је прво локализован од стране аутора читанке и објашњена је структура саме књиге (за разлику од читанке издавачке кућe Klett), ради потпунијег разумевање одломка, али и подстицања ученика на читање дела у целости. ${ }^{14}$ Међу осталим наведеним прозним текстовима, који сваки у себи носи необичност и занимљивост, не уочава се критеријум по којем су одабрани за читање у настави књижевности или се не уочава значењска веза са прописаним програмским текстовима, што може сугерисати проширење програмског оквира и спектар методичких могућности.

За изборне текстове у читанкама за четврти разред важи исто што је речено за претходне читанке: неуједначеност у њиховом броју и обиму, недовољно

${ }^{14}$ Овде би се поново могла поменути прича о угледању, посебно када имамо у свести чињеницу да је читанка Вука Милатовића дуго година на тржишту и најдуже у употреби на овом узрасту. 
јасни критеријуми одабира и различит степен ослањања на обавезне текстове. Тачније, све је зависило од увида и стваралачке замисли аутора читанки и њиховог уживљавања у природу наставног програма, као и у лепоту, смисао, уметнички и образовни значај књижевног текста. Због узраста којем су намењене, ове читанке углавном имају развијенију методичку апаратуру, међутим то није разлог за скромнији избор текстова или за готово њихово непостојање, што је случај са уџбеником Симеона Маринковића и Славице Марковић (Креативни центар 2015б). У овој читанци дат је само један додатни текст „Шта ти ради телевизија" Дијане Плут и Љиљане Марковић (из њихове књиге Конфликти и шта са њима, истог издавача). За овај текст можемо рећи да се може сместити између слободног и усмереноизборног, јер сам програм (како је у уводу овог рада већ речено) у оквиру прописане лектире садржи и напомену о раду у настави на информативним текстовима из енциклопедија, часописа и књига за децу. С тога је јасно да поменута читанка не садржи ниједан додатни књижевноуметнички текст, нити текст који је у пуном смислу слободан ауторски избор.

Треба поменути да у изборне текстове улазе и за ученике, али и у неком ширем смислу, мање познати или готово непознати аутори. Неколико таквих текстова, од укупно 8 унетих текстова, налазимо, на пример, у читанци издавачке кућe Eduka (Тодоров и др. 2016), иако бисмо можда очекивали већи број аутора који припадају класицима домаће и светске књижевности. С друге стране, у слободном избору ове читанке нашла се и прича „Бела и жута девојчица” познатог писца Перл Бака. Текст нам доноси не толико честу тему у читанкама за разредну наставу, и отвара данас веома актуелна питања међусобног разумевања и поштовања раличитости.

На другој страни, као сасвим супротан пример стоји читанка издавачке куће БИГЗ (Аранђеловић 2015), која садржи 25 додатних текстова. ${ }^{15}$ У додатном избору нашли су се одломци из култних романа: Хајди Јохане Шпири, Петар Пан Џејмс Метју Барија, Къига о иунгли Радјард Киплинга, Робин Худ Џон Финмора, Леси се враћа кући Ерик Најта. Јасна је намера ауторке Мирјане Ј. Аранђеловић да ученике овог узраста упозна са класицима светске књижевности за децу и да их заинтересује за читање целовитог дела, што је у општем контексту кризе читања данас веома важно и похвално. ${ }^{16}$ Изборни текстови у овој читанци веома су разноврсни. Жанровска и тематска разноврсност изборних текстова, као и њихово потицање из различитих периода, врло су важни за ученике још од најранијег школског узраста, већ од периода описмењавања и формирања ма-

${ }^{15}$ Ипак, то је и читанка са највише изостављених програмом задатих текстова у четвртом разреду. Драмски текст Добрице Ерића „Чик да погодите због чега су се посвађала два златна брата”, одломак из „Пепељуге” Александра Поповића, из мемоара Михајла Пупина Од пашњака до научењака, романа Алиса у земљи чуда, Бела грива и Бескрајна прича, као и избор из поезије Милована Данојлића и бајки Гроздане Олујић, нису се нашли у овој читанци. (Наставни програм прописује бајку „Олданини вртови”, као и избор из других бајки Гроздане Олујић. Међутим, додатни избор не постоји ни у овој, као ни у већини других читанки.)

${ }^{16} \mathrm{O}$ кризи читања и последицама овог проблема на основношколском узрасту видети више у: Јанићијевић, Митровић, Марковић, 2018. 
лих читалаца, јер им омогућавају да изграде садржајнији и потпунији поглед на књижевност и да боље реагују и на форму и на садржај текста (в. Бут и Сворц 2009: 24). Осим јасне намере ауторке да ученицима понуди што различитије теме, мотиве и жанрове, за поједине текстове не уочавају се додатни разлози одабира.

Са друге стране, код једног броја текстова постоји видљива тематска повезаност са текстовима из програма. Тако у неколико наврата изборни текст прати програмом задат. Након одломка „Прва љубав” из Нушићеве Аутобиографије ауторка доноси песму по сопственом избору „Прва љубав” Мирослава Антића. Драмски текст Зорице Симовић „Трноружица се буди” наставља се на бајку браће Грим „Трнова Ружица”. Слично, али још суптилније бирање додатног текста који је у вези са обавезним, видимо на примеру песме Бране Црнчевића „Кад би мени дали”. Песма се завршава стиховима: „Кад би мени дали један дан / ја га не бих потрошио сам.”, а потом ауторка бира одломак о пријатељству и $n p u-$ питомљьвању другог бића из Малог принца - део у ком главни јунак проговара о везаности и одговорности према својој ружи. На оквирима наведене читанке опет уочавамо брижљив одабир слободноизборних текстова. Читанку отвара кратка „Прича о мастилу и хартији” Леонарда да Винчија, која говори о трагу и значају речи и писања, а затвара је исти аутор текстом „Мрав и зрно жита”, у којем посејано зрно кроз одређено време доноси бројне плодове. Одабир два текста добија смисао поуке о стицању знања учењем и читањем.

Ова читанка, поред поменутих изборних, садржи и осамнаест краћих непотписаних текстова (које можемо посматрати као део методичке апаратуре, те с тога нису ушли у коначан број додатних текстова у овој, као ни у осталим читанкама, и нису били предмет наше анализе), по чијој природи би се могло закључити да је реч о нешто слободнијој, али веома доброј стилизацији коју је на основу једног или више извора сачинила сама ауторка уџбеника. Поједини од ових текстова су прави мали бисери енциклопедијског типа.

У нашој анализи поменућемо још две читанке у којима се види одређен искорак и веће промишљање у избору текстова, као и потреба аутора да читаоцима што више раскрили улазак у свет књижевности, нудећи на једном месту богатство и разноврсност аутора, стилова и жанрова. У првом од њих, а то је читанка издавачке куће Klett (Радмила Жежељ Ралић 2016в), видимо како се на броју страна сличном већини читанки, поред свих програмом задатих, може донети још 14 изборних, а након сваке целине и 8 текстова који нису могли бити предмет наше детаљне анализе, али су, како смо већ рекли, сјајни примери добро обликованих енциклопедијских знања. ${ }^{17}$

17 Читанка носи назив Речи чаробинице, а на крају прве тематске целине наилазимо на текст „Чаробница има чаролију”, а затим на крају осталих седам целина долазе текстови: „Чаролија речи - књига”, „Чаролија светлости - фотографија”, „Чаролија звука - радио”, „Чаролија цртежа и речи - стрип”, „Чаролија покретних слика - филм”, „Чаролија гледања и слушања на даљину - телевизија” и „Чаролија рачунарског света - интернет”. 
У избор Радмиле Жежељ Ралић ушли су и: одломак из познате приче (или како ауторка уџбеника каже поетске сликовнице) Моме Капора „Сања”; стилски врло занимљиво изведен и духовит текст Ђанија Родарија „Кад дедица не зна да прича приче”, који код ученика активира жанровска знања о бајци; ,Јутро на Месецу” Херберт Џорџ Велса и „Мјесечева прича” Григора Витеза - тематскомотивски уклопљене у целину у којој су и обавезни текстови „Мјесец и његова бака” Бранка Ћопића, односно „Прича о дечаку и месецу” Бранка В. Радичевића.

Други пример јесте читанка Завода за уџбенике (Опачић, Николић 2016). Међу 14 додатних текстова ауторке су ученицима представиле српске ствараоце који још увек нису део обавезне лектире у млађим разредима (Рајко Петров Ного, Бранко Стевановић, Дејан Алексић, Драгомир Ђорђевић, Александар Вучо, Игор Коларов, Гордана Тимотијевић), а чија дела представљају другачији израз у односу на онај који су ученици до сада читали. Посебно добро методичко решење јесте избор више песама истог аутора („Опет школа”, „Тесла” и „Прва љубав” Драгомира Ђорђевића), јер једино оваквим приступом је могуће размотрити поетику једног писца. Читанку отвара обавезни текст „Књига за Бастијана” у којем Бастијан проналази своју књигу за читање (одломак из Бескрајне приче Михаел Ендеа), следи више краћих одломака из романа „Алиса у земљи чуда”, а затим и изборни текст „Шта деца воле да читају” (одломак из дела Владимир из чудне приче Гордане Тимотијевић). Наведени примери постепено уводе ученике у свет књижевности, описују како тај свет настаје и шта деца воле да читају. Овакав смислен редослед одломака ауторке су искористиле и да на ваљан и поступан начин ученике упознају са појмом ромам, идеја (порука, поука) у књижевном тексту. У читанци је и, као додатни текст, одломак из популарног Толкиновог романа Хобит, одломци из два научнопопуларна дела „Међу Ескимима” Михаила Петровића Аласа и „Јутро на Месецу” Херберт Џорџ Велса. Сви наведени примери показују пуноћу и богатство света књижевности и на прави начин нуде ученицима путоказе кроз овај свет.

\section{Закључак}

Истраживање изборних текстова у читанкама још једном је показало непостојање одговарајућих упутстава за ауторе читанки. Тако се према резултатима до којих смо дошли види да се у неколико одобрених читанки не налазе сви програмом прописани текстови. Затим, да број изборних текстова и њихов однос према обавезним варира од издавача до издавача, од разреда до разреда и то у толикој мери да је тешко наћи било какву правилност у том варирању, као и јасан концепт аутора читанки или издавача, па чак и кад су у питању читанке истог аутора за различит узраст. Број додатних текстова у читанкама се креће од 28 (у једној читанци трећег разреда) до 1 (читанка за четврти разред). Код једног издавача највише изборних текстова је у првом разреду, а затим се њихов број постепено 
смањује. Код другог је ситуација обрнута, а код свих осталих од осам одобрених нема никаквог правила. Ни у једној читанци изборни текстови нису посебно означени. То и није обавеза аутора, али би било од користи за учитеље, посебно оне којима је читанка и замена за програм. Распон додатних унетих текстова у читанкама, њихова жанровска припадност и однос према обавезним текстовима је показао да је све препуштено ауторима читанки, рецензентима и издавачима.

Добра решења у појединим читанкама која се односе на ауторов додатни избор и њихову могућу (или претпостављену) везу са обавезним, такође показују да би упутства допринела умногоме квалитету читанки уопште. Тиме би се још више нагласила пожељна улога ових текстова. С једне стране, они сходно ученичком и наставниковом сензибилитету шире тематско и стилско поље књижевности, затим заједно са обавезним текстовима могу да развију одређене тематске и мотивске линије. Могу да послуже наставнику за потпунију обраду књижевних појмова, дела једнога писца, корелацију са другим областима наставе језика и са другим предметима, као и за стваралачке активности ученика. Ово је утолико значајније што се учитељи, у великој мери због природе свога посла и броја предмета које предају, у највећој мери ослањају на читанке.

За што квалитетнији допунски избор и смисленију повезаност додатних текстова и оних из обавезног програма, најбоље би можда било понудити учитељима корпус додатних конкретно пописаних дела (различитих по жанру, тематици, времену настанка, из српске и из светске књижевности) на основу којег би они бирали. Тај корпус мора садржати знатно већи број наслова од оних које учитељ реално може да искористи у настави у току једне школске године. То значи да учитељима на располагању треба да буду изузетно добри приручници за изборне текстове, хрестоматије текстова са одговарајућим сугестијама, коментарима и тумачењима, као и одређени број стручних семинара. Али да би се све то остварило, неопходно је да најважније просветне институције препознају и стручни и друштвени значај овог питања и да њихово решавање уграде у образовни систем. ${ }^{18}$

У настави књижевности се кроз сваки њен део и питања која покреће преклапају сви њени аспекти. То је случај, ово истраживање је то показало, и са слободним изборним текстовима. Због тога разматрање критеријума њиховог одабира може бити од значаја не само за будуће ауторе читанки, већ и за учитеље, јер се његовим резултатима изоштрава свест о односу прописаних и додатних текстова, о нужној допуни програмске лектире новим делима, као и о пажљивијем одабиру и функцији изборних текстова сходно сензибилитету

\footnotetext{
${ }^{18}$ Корпус понуђених текстова у новом наставном програму за пети разред из којег наставник бира додатне текстове за рад на часу сматрамо добрим решењем и оно је препоручљиво и за млађе разреде. Квалитетет тог установљеног и важећег пописа гарантовала би стручна јавност, а учитељ би бирао следећи потврђене, опште и личне критеријуме. Тада би и прича о мањем броју обавезних текстова имала више смисла и давала више наде за квалитетнијом наставом књижевности у млађим разредима.
} 
ученика и наставниковим увидима у најадекватније путеве за стварање младих читалаца.

\section{ЛИТЕРАТУРА}

Бут и Сворц 2009: D. But i L. Svorc, Uspešno čitanje i pisanje, tehnike za razvoj pismenosti, Beograd: Kreativni centar.

Гамбрел 1996: L. В. Gambrell, Creating clasroom cultures that foster reading motivation, Newark: The reading teacher, 50/1, International Literacy Association, Newark, 14-25.

Кларк и Румболд 2006: C. Clark and K. Rumbold, Reading for pleasure: A research overview, London: National literacu Trust.

Крашен 2004: D. S. Krashen, The power of reading: insights from the research, Santa Barbara: Libraries Unlimited.

Јанићијевић и др. 2018a: V. Janićijević, B. Marković i M. Mitrović, Reading: between compulsory reading and free choice - on the social and individual aspect of first literature classes, Arad: Journal Plus Education, vol. 20, no. 2, Aurel Vlaicu University of Arad, Arad, 2018, 83-103.

Јанићијевић и др. 2018б: V. Janićijević, M. Mitrović, B. Marković, Od obavezne lektire do ljubavi prema čitanju - kroz nastavne programe od Drugog svetskog rata do današnje reforme, u: M. Orel i S. Jurjevčič (ur.), Sodobni pristopi poučavanja prihajajočih generacij, Ljubljana: Eduvision, 2018, 314-331.

Марковић 2008: С. Марковић, Анализа допунских књижевноуметничких текстова у новим читанкама, Београд: Иновације у настави, XXI/2, Учитељски факултет, 60-71.

Марковић и Митровић 2017: Б. Марковић и Т. Митровић (ур.), Пикник за Ирму, Београд: Дом културе Студентски град.

Мосанд и Хендершот 2002: В. Mossand and J. Hendershot, Exploring sixth graders' selection of nonfiction trade books, Newark: The Reading Teacher, 56/1, International Reading Association, Newark, 6-17.

Мркаљ и Плут 2007: 3. Мркаљ и Д. Плут, Квалитет читанки за млађе ученике основне школе, у: Д. Плут (ур.), Квалитет уцбеника за млађи школски узpacm, Београд: Институт за психологију Филозофског факултета, 51-59.

Санакор 1999: J. Sanacore, Encouraging children to make choices about their literacy learning, Las Vegas: Intervention in School and Clinic, 35, University of Nevada at Las Vegas, 38-42.

Скрав и др. 1998: G. Schraw, F. Terri and F. Reisetter Marcy, The role of choice in reader engagement, Washington: Journal of Educational Psychology, 90/4, American Psyhological Associatinon, 705-714.

Хант 1997: L. C. Hunt, The effect of self-selection, interest, and motivation upon independent instructional, and frustrational levels, Newark: The Reading Teacher, 50/4, International Reading Association, Newark, 278-282. 
Џонс и Ванлеирсбург 1994: J. Johns and P. VanLeirsburg Promoting the reading habit: Considerations and strategies, In: Eugene Cramer and Marrietta Castle (ed.), Fostering the love of reading: The affective domain in reading education. Newark: International Reading Association, 91-103.

\section{ИЗВОРИ}

Аранђеловић 2015: М. Аранђеловић, Читанка за четврти разред основне школе, Београд: БИГЗ.

Вучковић 2011a: М. Вучковић, Румена свитања, читанка за први разред основне школе, Београд: Завод за уџбенике.

Жежељ Ралић 2015: Р. Жежељ Ралић, Маша и Раша - Игра речи, читанка за први разред основне школе, Београд: Klett.

Жежељ Ралић 2016а: Р. Жежељ Ралић, Маша и Раша - Царство речи, читанка за други разред основне школе, Београд: Klett.

Жежељ Ралић 2016б: Р. Жежељ Ралић, Маша и Раша - Река речи, читанка за трећи разред основне школе, Београд: Klett.

Жежељ Ралић 2016в: Р. Жежељ Ралић, Маша и Раша - Речи чаробнище, читанка за четврти разред основне школе, Београд: Klett.

Илић 2008: Б. Илић, Чаролија читана - читанка за трећи разред, Пожега: Епоха.

Јовановић 2010б: С. Јовановић, Златна јабука, читанка за први разред основне школе, Београд: Завод за уџбенике.

Јовановић 2015: С. Јовановић, Читанка за други разред основне школе, Београд: Завод за уџбенике.

Јовић и Јовић 2016: М. Јовић и И. Јовић, Читанка за први разред основне школе, Београд: Eduka.

Јоксимовић 2012: С. Јоксимовић, Моја прва читанка, читанка за први разред основне школе, Београд: Иновација Јоксимовић.

Јоксимовић 2015: С. Јоксимовић, Моја читанка, читанка за други разред основне школе, Београд: Иновација Јоксимовић.

Јузбашић и Тркуља 2008: М. Јузбашић и Н. Тркуља, Читанка 2, Читанка за други разред основне школе, Београд: БИГЗ.

Манојловић и Бабуновић 2016: М. Манојловић и С. Бабуновић, Читанка за други разред основне школе, Београд: Eduka.

Маринковић и Марковић 2015a: С. Маринковић и С. Марковић, Читанка за први разред основне школе, Београд: Креативни центар.

Маринковић и Марковић 2015б: С. Маринковић и С. Марковић, Читанка за четврти разред основне школе, Београд: Креативни центар.

Маринковић и Марковић 2016: С. Маринковић и С. Марковић, Читанка за трећи разред основне школе, Београд: Креативни центар. 
Маринковић и др. 2016: С. Маринковић, Љ. Маринковић и С. Марковић, Читанка за други разред основне школе, Београд: Креативни центар.

Милатовић 2015: В. Милатовић, Читанка за трећи разред основне школе, Београд: Завод за уџбенике.

НП 2004: Правилник о наставном плану и програму за први и други разред основног образовања и васпитања, у: Просветни гласник, Београд: Службени гласник РС, 10/2004.

НП 2005: Правилник о наставном плану и програму за први, други, трећи и четврти разред основног образовања и васпитања и наставном програму за трећи резред основног образовања и васпитања, у: Просветни гласник, Београд: Службени гласник РС, 1/2005.

НП 2006: Правилник о наставном програму за четврти разред основног образовања и васпитања, у: Просветни гласник, Београд: Службени гласник РС, $3 / 2006$.

Опачић и Пантовић 2016: 3. Опачић и Д. Пантовић, Прича без краја читанка са електронским аудио додатком за четврти разред основне школе, Београд: Завод за уџбенике.

ПСКУ 2016: Правилник о стандардима квалитета уџбеника и упутство за њихову употребу, у: Просветни гласник, Београд: Службени гласник РС, 42/2016.

Симовић 2008: Р. Симовић, Заједничка улазница, читанка за први разред, Пожега: Епоха.

Станковић-Шошо и Костић 2015: Н. Станковић-Шошо и М. Костић, Уз речи растемо, читанка за други разред основне школе, Београд: Нови Логос.

Станковић-Шошо и Костић 2016а: Н. Станковић-Шошо и М. Костић, Реч по реч, читанка за први разред основне школе, Београд: Нови Логос.

Станковић-Шошо и Костић 2016б: Н. Станковић-Шошо и М. Костић, $У$ свету речи, читанка за трећи разред основне школе, Београд: Нови Логос.

Станковић-Шошо и Чабрић 2016в: Н. Станковић-Шошо и С. Чабрић, Бескрајне речи, читанка за четврти разред основне школе, Београд: Нови Логос.

Тодоров и др. 2016: Н. Тодоров, С. Цветковић и М. Плавшић, Трешњ $а y$ цъвету - Читанка за четврти разред основне школе, Београд: Eduka.

Трнавац 2008: М. Трнавац, Кућа у разреду, читанка за 4. разред основне школе, Пожега: Епоха.

Ћук и Петровић 2006: М. Ћук и 3. Петровић, Добро јутро читанка за први разред основне школе, Београд: Нова школа.

Ћук и Петровић-Периц 2008a: М. Ћук и В. Петровић-Периц, Радости дружена читанка за трећи разред основне школе, Београд: Нова школа.

Ћук и Петровић-Периц 2008б: М. Ћук, и В. Петровић-Периц, Свет маште и знаға, читанка за четврти разред основне школе, Београд: Нова школа.

Ћук и Петровић-Периц 2009: М. Ћук и В. Петровић-Периц, Срећни дани, читанка за други разред основне школе, Београд: Нова Школа. 
Цветановић и др. 2016: 3. Цветановић, С. Копривица и Д. Килибарда, Читанка за први разред основне школе, Београд: БИГЗ.

Цветковић и др. 2016: М. Б. Цветковић, С. Цветковић, Т. Живановић, М. Плавшићи и Б. Првуловић, Водено огледало - читанка за трећи разред основне школе, Београд: Eduka.

Шојић и Касаповић 2008: В. Шојић и М. Касаповић, Читанка за трећи разред основне школе, Београд: БИГЗ.

Valerija B. Janićijević, Milena B. Janićijević

\section{ELECTIVE TEXTS IN READERS FOR CLASS TEACHING IN LITERATURE}

Summary

Elective texts in class teaching are as important as those determined by the syllabus reading. They are proposed by the authors of readers (whose selection the teachers can either trust or not), or selected independently by the teachers, based on their professional estimates, having in mind the students' emotional and intellectual interests. The paper gives a quantitative and qualitative analysis of elective texts in all the approved readers for the 2017/2018 school year. As there are no definitive binding instructions and criteria for selecting these texts, the paper examines hypothetical criteria and their impact on the quality of literature teaching. This research can be relevant to the future authors of readers, but also to the teachers, because its results raise the awareness of the relation between the set and additional texts, of the necessary addition of new works to the required reading, as well as of a more careful selection and function of elective texts that suit the students' sensibility and the teachers' knowledge of the most appropriate ways of rearing young readers.

Keywords: class teaching, literature teaching, curriculum and syllabus, reader, reading, elective texts, methodological apparatus. 